\title{
EDUCAÇÃ̃ DE IMIGRANTES POLONESES E A ATUAÇÃO DAS IRMÃS DA CARIDADE EM IRATI-PARANÁ (1930-1938)
}

\author{
Fábio $\operatorname{Kruk}^{1}$
}

\section{Resumo}

Este artigo apresenta a memória sobre a atuação das Irmãs da Caridade na educação dos imigrantes poloneses em Irati-Paraná, entre 1930 e 1938. A Escola Nossa Senhora das Graças, hoje administrada pela Secretaria de Estado da Educação, marcou o início da atuação dessas religiosas no município. As comunidades polonesas investiram recursos próprios para instruir seus filhos e realizar a transmissão dos valores culturais e religiosos aos descendentes. Para tanto, algumas congregações religiosas atuaram com esse propósito, entre elas, as Irmãs Filhas da Caridade de São Vicente de Paulo da Província Polonesa. A Escola Nossa Senhora das Graças teve uma origem étnica e posteriormente foi nacionalizada devido às exigências dos decretos estaduais e federais. A metodologia adotada decorre do uso das fontes orais, escritas e iconográficas como registros da memória que apresentam pistas para narrar uma história e constituir um "saber venatório" da educação dos filhos dos poloneses e da relação das irmãs com esses imigrantes.

Palavras-chave: Educação de imigrantes. Irmãs da caridade. Imigrantes poloneses.

\section{EDUCATION OF POLISH IMMIGRANTS AND THE ACTION OF THE SISTERS OF CHARITY IN IRATI-PARANÁ (1930-1938)}

\begin{abstract}
This article presents a report on the role of the Sisters of Charity in the education of Polish immigrants in Irati-Paraná between 1930 and 1945. The Nossa Senhora das Graças School, now administered by the State Secretary of Education, marked the beginning of the work of these sisters In the municipality. Polish communities have invested their own resources to educate their children and to transmit the cultural and religious values to their descendants. To this end, some religious congregations acted for this purpose, among them the Sisters of Charity of St. Vincent de Paul of the Polish Province. The Nossa Senhora das Graças School had an ethnic originand was later nationalized due to the demands of the state and federal decrees. The methodology adopted derives from the use of oral, written and iconographic sources as memory records that present clues to tell a story and constitute a "venatory knowledge" of the education of the children of the Poles and the relationship of the sisters with these immigrants.
\end{abstract}

Keywords: Immigrant education. Sisters of charity. Polish immigrants. 


\section{INTRODUÇÃO}

No Paraná, muitas escolas pertencem às congregações religiosas e estão localizadas principalmente em municípios que eram constituídos por colônias de imigrantes. Algumas são particulares e outras, vinculadas ao Estado, mantém o ensino público e gratuito. $\mathrm{O}$ interesse em como e por que algumas dessas escolas religiosas surgiram e continuam com suas atividades está relacionado aos imigrantes poloneses na região de Irati-Paraná.

No início da República, a política de imigração foi intensa no Paraná. Atraídos pela propaganda brasileira de fartura e abundância, imigrantes poloneses se instalaram no Estado e constituíram uma forma social determinante de várias colônias. A religião (igreja), a recreação (sociedade-clube) e a educação (escola), formas de representar o mundo ao dar sentido às suas ações e relações, determinaram o modus vivendi desses imigrantes. Nesse caso, ele torna-se uma representação das práticas e das necessidades sociais construídas pelos poloneses no passado. A instalação de escolas na região de Irati-Paraná se apresenta como expressão simbólica desses imigrantes para dar significado ao mundo onde passaram a viver. Conforme Pesavento (2003, p.15),

[...] a cultura é ainda uma forma de expressão e tradução da realidade que se faz de forma simbólica, ou seja, admite-se que os sentidos conferidos às palavras, às coisas, às ações e aos atores sociais se apresentam de forma cifrada, portanto já um significado e uma apreciação valorativa.

Os poloneses investiram recursos próprios com a preocupação de instruir seus filhos e realizar a transmissão dos valores étnico-culturais e religiosos aos descendentes. De acordo com Wachowicz (2002, p. 15), as escolas surgiram da necessidade dos poloneses alfabetizarem a descendência, constituindo numa importante etapa do processo de aculturação desses imigrantes. Outro motivo foi a ausência de escolas públicas no Brasil no início do século XX. As escolas polonesas funcionavam no mesmo espaço da sociedaderecreativa, onde eram realizadas recepções de autoridades, teatros, bailes e festas para arrecadar fundos para mantê-las e para pagar o professor. Esta instituição escolar-recreativa foi a primeira manifestação de aculturação do imigrante polonês no Brasil e, geralmente, eram leigas. (WACHOWICZ, 2002, p. 23-24). Segundo Kreutz (2003, p. 354-355), havia uma estrutura comunitária que apoiava essas escolas e integravam os poloneses com características do país de origem do grupo.

Além das escolas comunitárias leigas, existiam escolas mantidas por algumas congregações religiosas femininas que atuavam nas colônias. No Paraná, destacam-se as Irmãs da Sagrada Família e as Irmãs da Caridade de São Vicente de Paulo. A região de IratiParaná teve uma atuação intensa dessas congregações femininas católicas, que continuam mantendo suas atividades em Irati, Prudentópolis, Mallet e Rio Azul. Kreutz (2003, p. 363) afirma que o processo escolar dos imigrantes esteve vinculado à conservação dos valores religiosos e étnico-culturais e isso influiu na educação dos imigrantes poloneses.

Nesse artigo, pretende-se enfatizar uma das escolas religiosas existentes na região, no caso, a Escola Nossa Senhora das Graças, fundada pelas Irmãs da Caridade de São Vicente de Paulo, em Irati-Paraná, em 1930. O objetivo é apresentar a memória sobre a atuação dessas religiosas registrada nas fontes orais, escritas e iconográficas e, por meio dos 
seus indícios, constituir um "saber venatório" da educação dos poloneses nesse município, entre 1930 e 1938. Essa educação, ao envolver a religiosidade e o patriotismo desses imigrantes em relação ao país de origem, revela os interesses da Igreja Católica e a preocupação da política nacionalista brasileira nessa época.

Inicialmente, o artigo apresenta a imigração polonesa e a atuação da Província Polonesa das Irmãs da Caridade de São Vicente de Paulo no Paraná e em Irati, e, posteriormente, o "saber venatório" constituído pela análise indiciária da memória sobre a atuação dessas religiosas na educação dos filhos dos imigrantes poloneses nesse município.

\section{A IMIGRAÇÃO E A ATUAÇÃO DA PROVÍNCIA POLONESA DAS IRMÃS FILHAS DA CARIDADE DE SÃO VICENTE DE PAULO}

No final do século XIX, a Polônia estava dividida entre Rússia, Prússia e Áustria. O domínio político e os altos impostos ameaçavam os poloneses. Nessa mesma época, o governo paranaense incentivava a imigração para atrair mão-de-obra, principalmente europeia. Para Balhana (1996, p. 46-48), acreditava-se que a imigração estrangeira estabeleceria uma civilização camponesa aos modos europeus, formando colônias com distribuição de terras para a agricultura e abastecimento das cidades. Os colonos, camponeses europeus, desenvolveriam as mesmas atividades que faziam na Europa e com as mesmas técnicas. Fugindo da difícil situação em que se encontravam e atraídos pela propaganda da política imigratória, muitos poloneses imigraram para o sul do Brasil. Os primeiros chegaram ao Paraná em 1884 e vieram de Santa Catarina, onde tiveram dificuldades de se adaptar, fixando-se nas colônias de Pilarzinho e Abranches, hoje bairros de Curitiba. Desde então foi grande a corrente imigratória para o Estado. De 1890 a 1896 cerca de 28000 poloneses adentraram o território para trabalhar como lavradores, comerciantes ou profissionais liberais. (WACHOWICZ, 1997).

No início do século XX, Irati-Paraná recebeu as primeiras levas de imigrantes, principalmente de poloneses (1907-1912), holandeses (1908), ucranianos (1908) e alemães (1909). Conforme Wachowicz (1981, p. 120), dezenas de famílias polonesas vieram de Tomás Coelho para Irati, Rio Azul e Teixeira Soares. Já havia na localidade do Alto da Serra algumas famílias polonesas, mas a partir de 1910, uma grande quantidade de imigrantes poloneses proveniente da região de Curitiba e de outras colônias como Rio Claro, Mallet e São Mateus do Sul se fixam no interior, nas localidades de Mato Queimado, Rio do Couro, Rio Corrente, Coxinhos, Pedra Preta e também na sede municipal. (SOCIEDADE BENEFICENTE CULTURAL IRATIENSE, 1996, p. 7). Em 1908, o município possuía colônias financiadas pelo governo federal, entre elas, Xavier da Silva e Gonçalves Júnior, além de muitas terras demarcadas para atrair outros imigrantes. (PARANÁ, 1908).

Irati-Paraná se desenvolveu devido ao intenso comércio criado pela Estrada de Ferro São Paulo - Rio Grande do Sul, a partir da qual se formou. Nas redondezas da estação de Irati havia madeireiras, depósitos de erva e casas de comércio variadas: bodegas, confeitarias, salsicharias. O comércio tornou-se importante para o crescimento da vila. (I LIVRO TOMBO DE IRATY, 1920-1966, p. 2-5). Os poloneses eram atraídos pela colocação de produtos no mercado paulista com a estrada de ferro; à extração de madeira e 


\section{Revista HIISTEYIDIR On-line}

erva-mate e à fertilidade do solo que tornava possível a agricultura. (SOCIEDADE BENEFICENTE CULTURAL IRATIENSE, 1996, p. 4). Dessa forma, participaram ativamente do comércio, fundaram serrarias e moinhos e exploravam a erva-mate. Outros se destacavam como profissionais liberais e artesãos, mas a grande maioria era agricultores.

Os imigrantes poloneses trouxeram junto à capacidade de trabalho valores e sentimentos que os ligavam à Polônia. A vida comunitária, a religiosidade e a língua eram elementos que expressavam o que Wachowicz (1981, p. 95) chamou de polonidade, ou seja, a ligação que possuíam com o país de origem. Em praticamente todas as comunidades, os poloneses fundavam igrejas e sociedades recreativas e escolares. Dessa forma, se integravam e davam sentindo às suas relações, à vida e ao mundo em que viviam, transmitindo seus valores e sentimentos aos descendentes.

Nesse período, a Igreja Católica buscava expandir e renovar o seu domínio sobre a população, a chamada romanização, com a fundação de dioceses e arquidioceses. Isso vinha ao encontro das mudanças propostas pelo Concilio Vaticano I (1869-1870) na organização do catolicismo, entre elas, a intervenção maior do Papa e a reorganização da Igreja. (KUBASKI, 2015, p. 99-100). Conforme Capri (2003, p. 48), a vinda de congregações religiosas fazia parte de uma etapa em escala mundial e o processo desenvolvido pelos membros da Igreja era de recuperar para a instituição um lugar central na sociedade.

Em 1904, o bispo da região de Curitiba, Dom José de Camargo Barros, solicitou à Província de Chelmno, na Polônia, a vinda das Irmãs Filhas da Caridade ao Paraná. Luiza Olsztynska, Natália Zietak e Leocádia Suchoswiat chegaram a Paranaguá no dia 17 de outubro de 1904. Essas irmãs vieram para atender aos filhos dos poloneses estabelecidos na colônia de Abranches, hoje bairro de Curitiba. Ao lado da Igreja de Santana, fundaram o Colégio São José. A Província de Chelmno enviou várias Irmãs polonesas para o Paraná, no total de doze viagens. O Brasil foi o primeiro país de atuação das Irmãs da Caridade da Polônia. (FERREIRA, 1974, p. 25). Nas áreas de imigração polonesa, a Igreja Católica fazia um trabalho missionário com a intenção de ampliar seus domínios e controlar seus fiéis. Para tanto, escolas, hospitais, asilos e orfanatos eram construídos para aproximá-la da sociedade. (RENK, 2009, p. 53).

A comunidade polonesa da sede de Irati-Paraná preocupou-se com as questões étnico-culturais e, por serem católicos, com o centro religioso. Em 1919, formou-se uma comissão para a construção da Igreja de São Miguel e em 1921 fundaram Towarzystwo Polskie Wolność - Sociedade Polonesa Liberdade, onde funcionava uma escola polonesa que ensinava os filhos dos imigrantes em língua polonesa e em língua portuguesa. (SOCIEDADE BENEFICENTE CULTURAL IRATIENSE, 1996, p. 7-8).

Desde 1925, os poloneses já se esforçavam em trazer as Irmãs da Caridade a IratiParaná. A falta de religiosas e o processo de criação da Diocese de Ponta Grossa dificultavam a questão. Para garantir a vinda das irmãs polonesas, doaram quatro terrenos com três casas de madeira ao lado da Igreja de São Miguel. (GÓRAL, 1929, p. 76). Em 12 de agosto de 1930, a Província Polonesa das Filhas da Caridade de São Vicente de Paulo iniciou sua atuação em Irati-Paraná com a fundação da Escola Nossa Senhora das Graças. 


\section{Revista HIIST'TEIDBR On-lime}

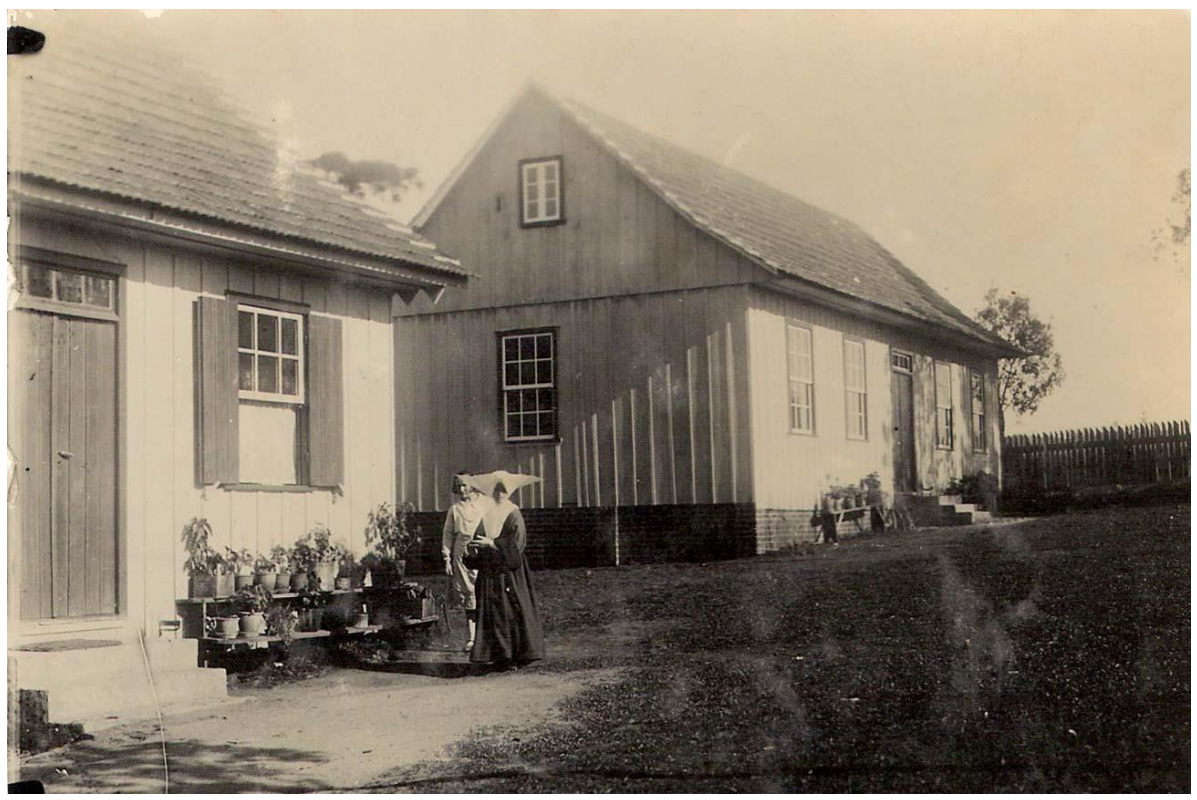

Figura 01 - Instalações provisórias da escola das Irmãs da Caridade. Fonte: Casa da Cultura/Museu Municipal de Irati.

Em 1937, o Paraná possuía 167 escolas polonesas, sendo 30 religiosas. Dessas, 12 pertenciam às Irmãs da Caridade. (WACHOWICZ, 2002, p. 67-68). A atuação das religiosas em Irati-Paraná coincide com a busca da política nacionalista pela padronização do ensino. Desde os anos 1920, a política de nacionalização tentava implantar um programa de educação que nacionalizasse e homogeneizasse a população afastando o risco de impedimento da identidade nacional. (BOMENY, 1999, 151-153). Nesse momento, a escola passou a ter um papel central na configuração de uma identidade nacional e tornou-se um fator de incentivo à exclusão, inclusive das escolas de imigrantes.

No início, a escola das Irmãs da Caridade possuía caráter étnico, mas posteriormente foi nacionalizada devido às exigências dos decretos estaduais e federais. De acordo com Kreutz (2010, p. 72-83), muitos decretos-leis foram instituídos a partir de 1937 com medidas repressivas de nacionalização que causaram o fim das escolas étnicas e com o objetivo de criar o maior número possível de escolas públicas nas colônias de imigrantes. Foi nesse contexto que algumas escolas polonesas mantidas pelas congregações religiosas mantiveram suas atividades, mas nacionalizadas.

\section{OS LUGARES DE MEMÓRIA E O "SABER VENATÓRIO"}

As fontes orais, escritas e iconográficas apresentam pistas sobre a atuação das Irmãs da Caridade de São Vicente de Paulo na educação de imigrantes poloneses realizada na Escola Nossa Senhora das Graças, a partir de 1930. Essas pistas "[...] talvez infinitesimais permitem captar uma realidade mais profunda, de outra forma inatingível" (GINZBURG, 1989, p. 150) abrem possibilidades de utilizar a memória para a escrita da história. Além de dados, ela fornece fragmentos dispersos que entrelaçados constituem o entendimento dos sujeitos que estiveram vivendo as relações sociais e culturais de um contexto, de uma época. 
Para tanto, foram utilizados entrevistas feitas pelo autor, discursos de alunos que estudaram na época e fotografias como lugares da memória. Nora (1993, p. 7-9) evidencia que na busca incessante pelo lembrar, o homem cria lugares onde possa guardar suas ações realizadas no tempo. Esses lugares cristalizam e refugiam a memória, possibilitando uma interpretação da sociedade no passado pela sua presença material no presente, expressando-se também de forma simbólica e funcional. São espaços que se apresentam como restos, vestígios e testemunhos do que já passou. As fontes utilizadas nesse artigo são lugares diversificados que guardam a memória individual.

A presença material existente em forma de entrevistas e discursos recorre a técnicas para produzi-la e, nesse caso, deve se considerar as intenções dos responsáveis na procura e na produção desses lugares. A utilização da memória, para a análise da história, necessita de uma proposta que permita recuperá-la. Thompson (1992, p. 137) avalia a contribuição da história oral como técnica utilizada por historiadores, sociólogos e jornalistas na realização de várias obras e estudos. Para ele, a evidência oral, transformando os "objetos" de estudo em "sujeitos", contribui para uma história que não é só mais rica, mais viva e mais comovente; também mais verdadeira. Porém, é preciso considerar que os significados das lembranças estão relacionados aos valores apreendidos pelos sujeitos em momentos específicos e necessários para atribuir sentido ao mundo e às relações por ele vividas. Por isso, não se pode confundir história oral e memória. A memória é formada por lembranças, é sempre dinâmica, muda e evolui constantemente. A história oral é uma busca de informações ou registros da experiência vivencial, que está atenta à inserção do indivíduo na sociedade e não na relação do depoente com suas lembranças. (MEIHY, 1996, p. 13). O que será considerado nessa escrita são as lembranças da experiência vivencial dos ex-alunos da escola e moradores de Irati como informações, dados, registros. Mesmo que os lugares de memória não estejam diretamente voltados para a educação dos imigrantes poloneses, podem ser utilizados para fornecer dados, pois guardam ou até mesmo recuperam as ações dos sujeitos realizadas em certo tempo e, portanto, apresentam indícios da educação realizada na escola.

As fotografias que compõe o artigo também se tornam pistas. Enquanto registros da memória revelam uma intenção em guardar um acontecimento, uma realização da comunidade e, enquanto testemunho e vestígio, possibilita um entendimento do passado. Não é apenas uma escolha do historiador utilizá-las como presença material no presente, mas foi uma escolha dos sujeitos em registrar, no passado, o que queriam que fosse lembrado.

Sendo assim, para apresentar a memória sobre a atuação das Irmãs da Caridade na educação dos filhos de imigrantes poloneses, um "saber venatório" foi constituído com indícios imperceptíveis. As lembranças fragmentadas nos lugares de memória tornaram-se pistas para narrar uma história com uma série coerente de eventos. Ao analisá-los, extraíramse as lembranças referentes à educação de imigrantes poloneses. Houve, portanto, uma apropriação dessas lembranças como pistas para narrar ao exemplo do caçador "[...] porque era o único capaz de ler, nas pistas mudas (se não imperceptíveis) deixadas pela presa, uma série coerente de eventos". (GINZBURG, 1989, p. 152). Elas forma analisadas e conectadas para dar forma a um conhecimento histórico conjetural. Enquanto lembranças, as pistas pertenciam à memória. Enquanto fonte, o lugar da memória disponibiliza essas pistas para a escrita da história. 
O que caracteriza esse saber é a capacidade de, a partir de dados aparentemente negligenciáveis, remontar a uma realidade complexa não experimentável diretamente. Pode-se acrescentar que esses dados são sempre dispostos pelo observador de modo tal a dar lugar a uma sequiência narrativa, cuja formulação mais simples poderia ser "alguém passou por lá". (GINZBURG, 1989, p. 152).

Como o "[...] saber venatório [...]" é um conhecimento produzido pelo "[...] faro, golpe de vista, intuição [...]" (GINZBURG, 1989, p. 179), os lugares de memória foram atentamente observados para a formação de outro - a narrativa, uma história.

\section{EDUCAÇÃO DE IMIGRANTES POLONESES E A ATUAÇÃO DAS IRMÃSDA CARIDADE EM IRATI-PARANÁ (1930-1938)}

As Irmãs da Caridade participaram do processo escolar dos poloneses em IratiParaná. As lembranças imperceptíveis nos lugares da memória e apropriadas como pistas permitiram compor uma sequência narrativa. Os eventos apresentados: a relação da comunidade polonesa com as religiosas, a chegada, a escola provisória, a construção da escola e as práticas educacionais remontam uma realidade vivida pelos sujeitos que permitiram guardar a memória. Acessar as suas vivências como expressões simbólicas nos mostram as relações culturais estabelecidas por eles no passado. Dessa forma se tem uma história da educação sobre a perspectiva da etnia, ou seja, um processo educativo enquanto dinâmica histórica construída pelas práticas sócio-culturais dos sujeitos e envolvidas por tensões, conflitos e alianças. A análise sob essa perspectiva mostra como determinado grupo se entende, que conflitos tem entre si e com os outros e o que ele constrói nesse entrecruzamento. (KREUTZ, 1997, p. 129-132).

Em Irati-Paraná, já existiam escolas públicas isoladas e em 1924 já contava com um grupo escolar: o Grupo Escolar Iraty. (ZANLORENZI, 2012). Mesmo assim, as comunidades polonesas instalavam suas escolas étnicas. No Alto da Serra havia a Sociedade escolar Henrique Sienkiewicz, na cidade foi construída a Sociedade Liberdade, na localidade de Rio Bonito instalou-se a Sociedade Wicente Witos e na Colônia Irati a Sociedade José Pilsudski. (GLUCHOWSKI, 2005, p. 156). Conforme o discurso de Zeni (1990), os católicos poloneses auxiliaram na construção da Escola Nossa Senhora das Graças. Formou-se um movimento na busca pelo ensino básico com atendimento de internato e externato e sob a orientação de uma entidade religiosa, no caso as Irmãs Filhas da Caridade de São Vicente de Paulo.

Essas escolas instituídas pelas comunidades polonesas possuíam um caráter étnico, pois a escola expressava os valores necessários para a formação dos sujeitos. Nesse caso, os valores étnico-culturais e religiosos permitiam assegurar a preservação da identidade por meio da língua e da religiosidade. Os sentimentos patrióticos e religiosos configuraram a polonidade, elemento característico dessa identidade. Para Kreutz (1997, p. 133), a análise da escola como espaço sócio-cultural resgata o papel dos sujeitos na trama social que a constituiu enquanto instituição. Sendo assim, o termo étnico aqui apresentado refere-se à estrutura tanto de percepção quanto de organização concreta e simbólica da vida social. Por meio da perspectiva étnica, os sujeitos se tornam visíveis, aparecem se construindo no 


\section{Revista HIISTEYIDIR On-line}

processo histórico-escolar por meio das práticas sócio-culturais. (KREUTZ, 1997, p. 136137).

Devido à imigração, sacerdotes poloneses eram designados para prestar assistência às comunidades de imigrantes e tornavam-se responsáveis pela inserção desses sujeitos na religião e na preservação da cultura. Em alguns casos, como em Irati-Paraná, apaziguavam a tensão entre brasileiros e poloneses. A língua gerou conflitos na capela Nossa Senhora da Luz, o que dificultava a instalação da paróquia. Por isso, em 1920, o bispo de Curitiba designou o padre Casimiro José Andrzejewski para resolver os conflitos na vila. (I LIVRO TOMBO DE IRATY, 1920-1966, p. 2-5). Além dele, outros sacerdotes poloneses I atuaram no município, dos quais se destaca o vicentino Paulo Warkocz. Irati já possuía a presença dos vicentinos da Congregação da Missão representada pelo Seminário São Vicente de Paulo. Isso colaborou para a vinda das primeiras Irmãs da Caridade ao município. Havia sempre a preocupação de que as escolas fossem abertas onde estava assegurada a presença desses sacerdotes. Padre Paulo atuou também na capela São Miguel que contava com muitos fiéis, sendo a maioria de poloneses. Conforme Antônio Pavelski Sobrinho ${ }^{2}$, descendente de poloneses entrevistado pelo autor, a sociedade solicitou as Irmãs para trazer a religião mais perto e o padre Paulo foi responsável pela vinda da congregação, pois já estava em Irati e atuava na Igreja Nossa Senhora da Luz. Para o entrevistado, Irati era uma cidade polonesa e havia muito contato entre Irati e a Polônia. (PAVELSKI, 2001). Percebe-se que o processo escolar dos poloneses estava relacionado a esse motivo religioso e para garantir os valores étnico-culturais, como a língua. Para Renk (2009, p. 52), a família, as escolas, a rede de sociabilidades, os laços de parentesco, as associações culturais e a igreja foram fundamentais para a conservação da língua que identificavam esses imigrantes.

A nomeação de D. Antonio Mazzarotto, em 3 de maio de 1930, como primeiro bispo da Diocese de Ponta Grossa, acelerou a criação da paróquia de Nossa Senhora da Luz em março de 1931, que teve como primeiro vigário e pároco o padre Paulo Warkocz, e a permissão oficial da vinda das Irmãs da Caridade de São Vicente de Paulo, conforme pedido da colônia polonesa. O I Livro Tombo de Iraty registra a fundação da escola das Irmãs da Caridade, em 1930.

A 12 de agosto, vindas de Curitiba, chegam a Iraty as duas primeiras irmãs da Caridade, nomeadas para virem abrir um collegio de curso primário e secundário em Iraty onde já possuem um terreno e pequena casa por doação dos polacos, perto da Igreja de São Miguel, nesta cidade. A superiora é a Irmã Helena Olek e a sua companheira a Irmã Irene, ambas polacas. Desde o dia 14 de agosto o Santíssimo Sacramento foi conservado na dita Igreja de São Miguel. (I LIVRO TOMBO DE IRATY, 1920-1966, p. 11).

Para Panka (1985) foi um dia ensolarado e os iratienses esperavam a chegada de Helena Olek e Edwirges Miketta. Ela, seu pai e irmãos foram esperá-las às cinco horas da tarde na estação ferroviária. Lá estavam carroças vindas de várias colônias. As famílias trouxeram leite, manteiga, broa, ovos, galinhas para doarem para as irmãs. O clima era de grande festa.

As irmãs foram levadas da estação ferroviária até à Rua 19 de Dezembro, onde estavam as instalações provisórias, pelo casal José e Josefina Fillus. Durante o trajeto as conversaram sobre o projeto de construir um grande estabelecimento de ensino em Irati para 


\section{Revista HIIST'NDBR On-lime}

atender não somente as necessidades daquele momento, mas as futuras, e para tanto precisavam adquirir os terrenos próximos às instalações provisórias. (VALENGA, 2002, p. $51-52)$.

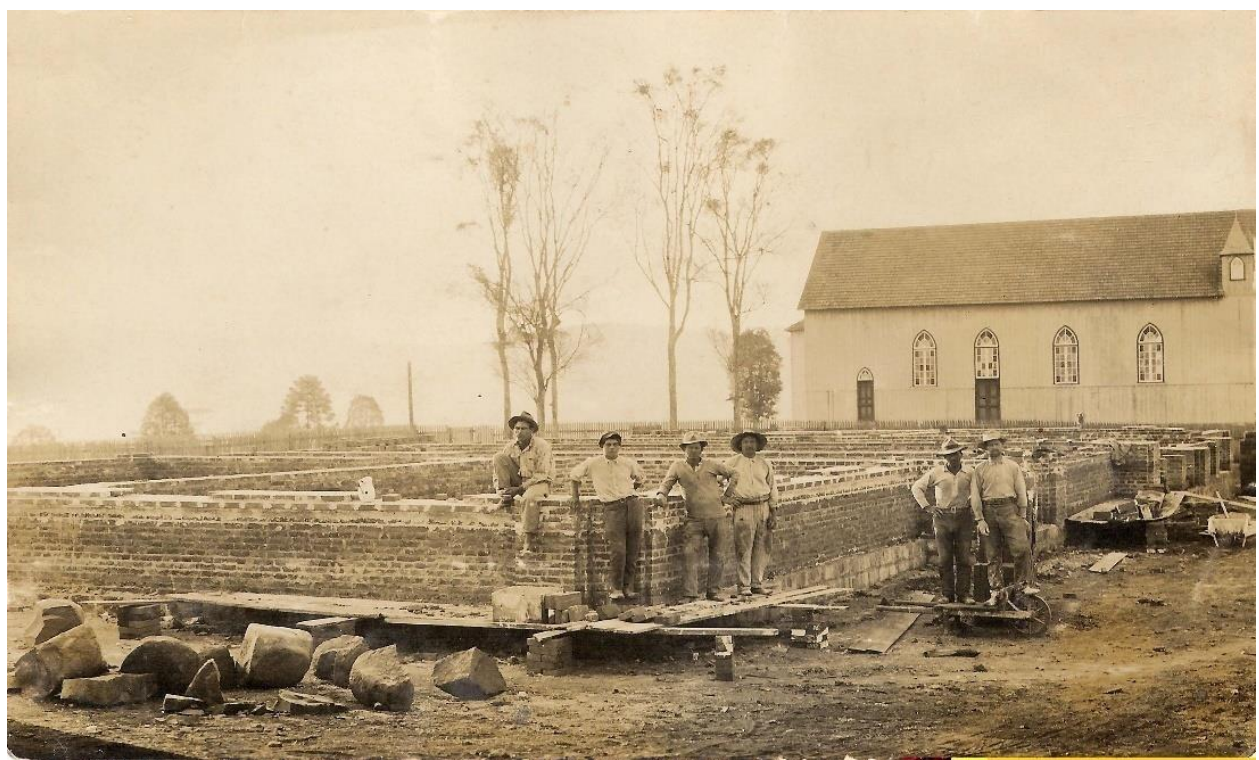

Figura 02 - Construção da Escola Nossa Senhora das Graças. Ao fundo, Igreja São Miguel. Fonte: CEDOC/I - Centro de Documentação e Memória da Unicentro/Irati.

A fundadora da Escola Nossa Senhoras das Graças, Irmã Helena Olek, atuava na Polônia como professora do jardim de infância e durante a sua missão no Brasil atuou em escolas e orfanatos. Das 12 viagens promovidas pela Província de Chelmno, na sétima, em 1921, veio a irmã Helena Olek, e na oitava, a irmã Edwirges Miketta. (FERREIRA, 1974, p. 25).

As escolas religiosas tornaram-se instituições estratégicas para a Igreja, para a formação de católicos de acordo com os princípios romanizantes. (CAPRI, 2003, p. 85). A primeira visita pastoral feita por D. Antonio Mazzarotto a Irati, em 10 de dezembro de 1930, acompanhada do padre Paulo Warkocz, mostra a importância dessas escolas para a Igreja Católica. Em carta enviada ao padre, o bispo registrou suas impressões sobre o povo, a religiosidade e as expectativas para o futuro da comunidade. Mostrou-se preocupado com a formação de catequistas e com a catequese das crianças e adultos. Escreveu que as associações ordenadas por ele para serem fundadas poderiam colaborar para o progresso da religião no município, inclusive, a escola recém fundada pelas Irmãs da Caridade. (I LIVRO TOMBO DE IRATY, 1920-1966, p. 17). O progresso da religião seria a expansão do catolicismo.

Havia na região uma divisão da colônia polonesa em relação à religiosidade que preocupava os interesses da Igreja Católica e a fazia investir nas escolas. Tratava-se da Igreja Velho Católica, representada em Irati pelo padre Theophilo Bartnicki.

A Igreja Velho Católica ou Antigo Católica consistia nas igrejas livres derivadas da Igreja Católica que surgiram em alguns países europeus e nos Estados Unidos, a partir de 1871, contrárias a alguns dogmas estabelecidos no Concilio Vaticano I, principalmente a 
infalibilidade papal. Mesmo assim, se diziam iguais na fé e no culto. Em 1904, o sacerdote polonês Francis Hodur fundou na Pensilvânia, nos Estados Unidos, a Igreja Nacional Polonesa que atendia aos imigrantes poloneses estabelecidos naquele país. Após a Primeira Guerra, foi criada uma sucursal na Polônia, que desde 1926, espalhava-se pelos países onde havia imigrantes poloneses. (CAPRI, 2003, p. 94-95).

Em Irati, a Kosciot Narodowe - Igreja Nacional era subordinada a uma central dos Estados Unidos, sem ligação com Roma, e seus seguidores eram chamados narodowcy nacionalistas. A missa era em polonês e com andamento similar ao da Igreja Católica. (FARAH et al. 2008, p. 81). Entre as questões para o surgimento dessa igreja nas colônias polonesas estava o fato de o bispo representar a infalibilidade do Papa e colocar como questão o patrimônio da igreja, que deveria ser passado à mitra episcopal. (GLUCHOWSKI, 2005, p. 74).

Durante a década de 1920 e 1930, a Igreja Católica realizava a efetivação do processo de romanização no Brasil. Diante disso, era perigoso haver uma divisão dentro da comunidade católica polonesa. O padre Theophilo Bartinicki representou um problema para o bispo Antônio Mazzarotto na região. Em Ponta Grossa, o bispo e o padre discutiram por meio de artigos publicados no Jornal Diário dos Campos. Até o Consulado Polonês teve que se envolver para buscar uma conciliação, mas havia a dúvida do seu posicionamento político e ideológico. (CAPRI, 2003, p. 90-98). Em Irati, segundo Farah et al. (2008, p. 81), logo após a instalação da Igreja Nacional Polonesa, houve desencontro de opiniões entre o padre Bartinicki e o padre Paulo Warcocz. Nesse caso, a dúvida sobre a liderança do bispo e sobre o patrimônio da comunidade ligado à Igreja dividiu os poloneses e nem todos eram adeptos das novas práticas católicas.

Diante disso, a escola das Irmãs da Caridade teria um papel fundamental para os interesses da Igreja Católica e para espalhar os princípios romanizantes por meio da educação. As escolas católicas eram vistas como verdadeiras escolas pelo Papa Pio XI, pois buscavam a valorização da família e o engrandecimento da nação. $O$ cidadão católico poderia respeitar qualquer poder instituído desde que respeitasse sua catolicidade. Sendo assim, a Igreja Católica trabalhava com o civismo e com a religiosidade para expandir os seus domínios e a escola católica se transformava numa instituição formadora de hábitos para esses fins. (CAPRI, 2003, p. 90-98). Na imagem abaixo, isso pode ser observado. 


\section{Revista HIIS'TEDIBR (Dn-line}

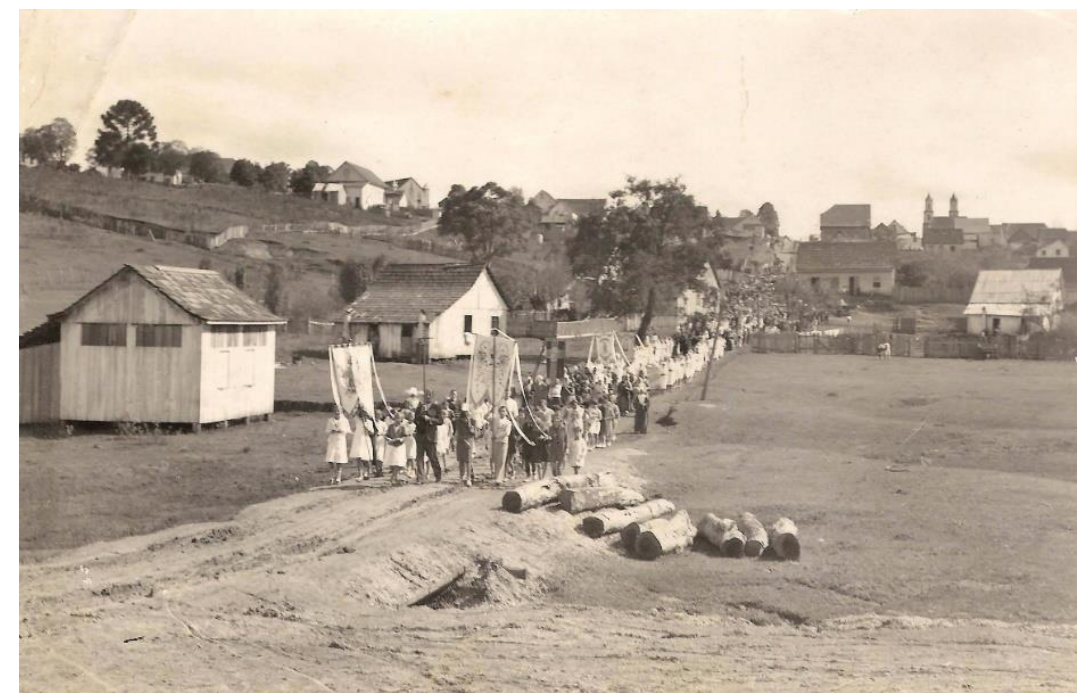

Figura 03 - Procissão religiosa. No canto superior direito, Igreja Nacional Polonesa. Fonte: Casa da Cultura/Museu Municipal de Irati e CEDOC/Unicentro.

De acordo com o depoimento de Panka (1985), alguns alunos mudaram da escola polonesa Liberdade para a escola das irmãs que funcionava com duas salas de aula. A Irmã Helena Olek dava aula e a irmã Irene ensinava os cantos escolares e religiosos. No dia da inauguração, Padre Paulo fez um discurso empolgando a todos e o Sr. Alexandre Pavelski subiu num lugar elevado para saldar o povo com muita emoção. Edvirges Pereira ${ }^{3}$, uma das entrevistadas pelo autor, disse que estudou suas primeiras séries e aprendeu a língua de seus descendentes na Sociedade Liberdade (Clube Polonês). Dona Vica, como era conhecida, concluiu o primário na Escola Nossa Senhora das Graças, quando ainda funcionava em instalações provisórias. (PEREIRA, 2002). Segundo Wachowicz (2002, p. 37), as escolas das Irmãs da Caridade eram mais frequentadas que as escolas leigas porque possuíam professores com continuidade, eram mais baratas e davam mais confiança, sendo que algumas substituíram as sociedades-escolas. Além disso, eram estáveis devido ao ensino contínuo e não eram fechadas temporariamente desestimulando os pais e prejudicando o ensino. (GLUCHOWSKI, 2005, p. 171-173). Em Irati-Paraná, a escola das Irmãs da Caridade não interrompeu a atividade das sociedades escolares, contudo, representava um controle da Igreja Católica na comunidade.

Valenga (2002, p. 56-57) apresenta em seus relatos uma descrição do diálogo entre seu pai Leonardo Valenga e Josefina Fillus para a resolução da compra do primeiro terreno realizado pela Província Polonesa das Irmãs da Caridade em Irati. A parte frontal da escola foi construída onde se encontrava a residência dos lavradores Leonardo Valenga e Maria Valenga. A família então deu "[...] a última olhada para a casinha que dentro de pouco tempo deveria ser demolida, para dar lugar à nova construção que teria início dentro em breve". (VALENGA, 2002, p. 61).

A construção do prédio de alvenaria foi iniciada em fevereiro de 1931. Verônica Sidoski estudava nas instalações provisórias quando a construção da escola começou.

Os moradores ajudaram na construção com o incentivo do Padre Paulo Varkocz. Lembro-me que meu pai ajudou a puxar pedras com a carrocinha para a fundação. 


\section{Revista HIISTEIDBR On-line}

Na fundação não tem tijolos, é toda de pedras. Cada pedra enorme eles puxaram! (FILLOS, 2008, p. 50).

Os recursos financeiros para a construção eram conseguidos na realização de festas, brincadeiras e outras atividades na Rua XV de novembro. O dinheiro era recolhido pela comissão organizadora. Romeu Crissi ${ }^{4}$, entrevistado pelo autor, disse que ele e sua esposa trabalharam muito nessas comissões, fazendo doces para vender nas festas todas as noites. Havia sorteios, brincadeiras. O dinheiro arrecadado era destinado para a construção da Igreja Nossa Senhora da Luz, clubes, orfanato, asilo (CRISSI, 2002). Vitória Chaibe confirmou para o Jornal Hoje Centro Sul que "[...] na sua mocidade ajudaram, junto com a comunidade iratiense, a construir a Igreja Nossa Senhora da Luz e o Colégio Nossa Senhora das Graças através de festas, bingos e jogos na rua XV de Novembro".(CHAIBE, 2002, p. 10). Segundo Orreda (1980, p. 1) a obra foi concluída em 1937.

A escola das Irmãs da Caridade foi construída conforme os padrões arquitetônicos modernos da época, num lugar de grande visibilidade. Manifestava grandiosidade e admiração, valores que cerceavam o imaginário da sociedade e faziam as escolas se tornarem símbolos de modernidade. Os grupos escolares, modelos de escolas republicanas, inspiravam a construção de edifícios expressivos. (SILVA, 2006, p. 344-345). Mesmo sendo uma escola particular e estrangeira, o prédio dessa escola polonesa dirigida pelas Irmãs da Caridade estava inspirado nessas concepções e transmitia progresso e modernidade.

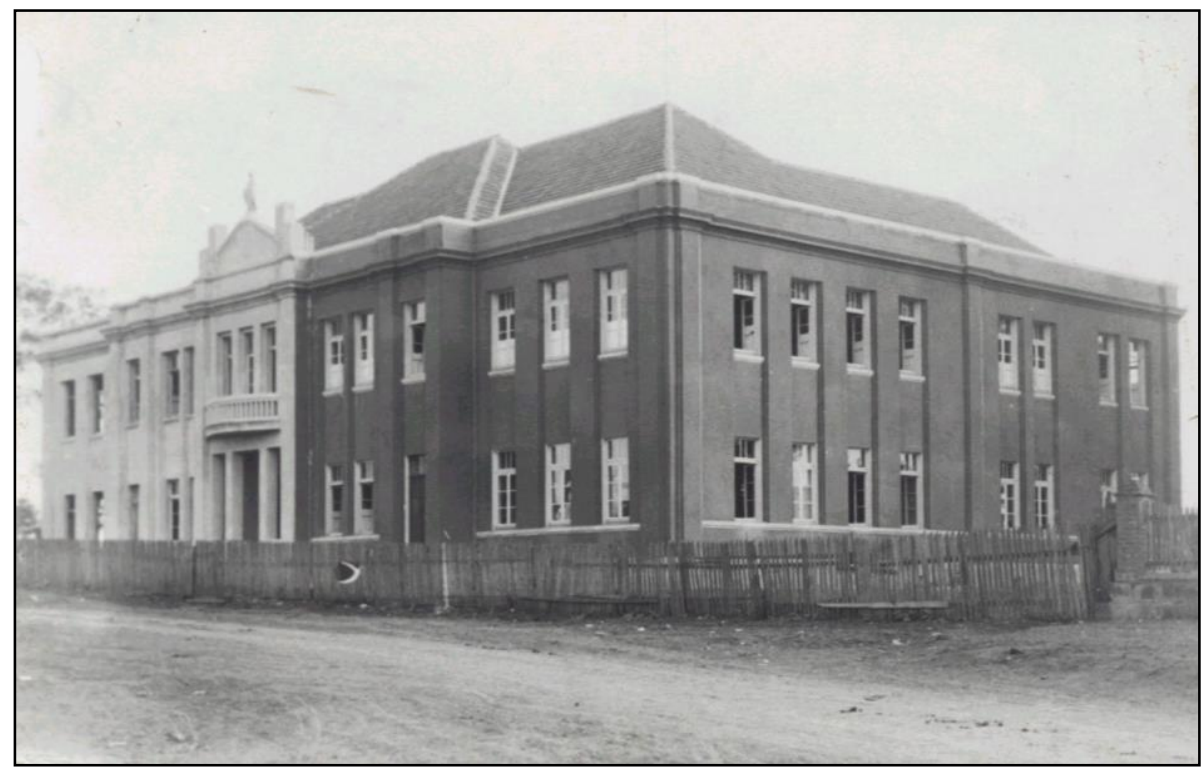

Figura 04 - Escola Nossa Senhora das Graças, em 1938. Fonte: Casa da Cultura/Museu Municipal de Irati.

A língua era um dos elementos que diferenciavam os imigrantes e lhes dava identidade. A ligação que tinham com a pátria de origem tornava o ensino na língua do grupo uma expressão dessa diferença. Por isso, o ensino nas escolas étnicas recebeu atenção especial das leis, principalmente em relação à língua do grupo. A língua polonesa “'[...] falada em espaços públicos (associações, comércio, imprensa e igreja), no lar, ensinada nas escolas, 


\section{Revista HIISTEYIDIR On-line}

Artigo

doi: $10.20396 /$ rho.v17i2.8645437

tornou-se objeto de preocupação da sociedade brasileira e da política de nacionalização do ensino". (RENK, 2009, p. 15).

Nessa época, a escola esteve vinculada aos grandes projetos políticos e sociais e corporificou a ideia de progresso constante da razão e da ciência. O discurso nacionalista colocou a educação como responsável pela realização dessa ideia e pela busca da homogeneização e da integração social. Para tanto, era necessário excluir o que era diferente e contrário a esses princípios, mas também silenciar tensões e alianças. (KREUTZ, 1997, p. 130-131).

Durante a Primeira República (1890-1930) e na década de 1930, as autoridades brasileiras buscavam implantar o projeto nacionalista brasileiro que fez da escola o principal instrumento para a criação de uma unidade nacional, com o discurso da integração a serviço da construção de um país moderno e com uma cultura homogênea. (BITTENCOURT, 1990, p. 25; 96). Desde a Primeira Guerra Mundial, as comunidades de imigrantes no Brasil despertaram as atenções dos governos e uma onda de nacionalismo apoderou-se das autoridades brasileiras. De acordo com Wachowicz (2002, p. 97), as comunidades estrangeiras se tornaram um motivo de inquietação por receberem financiamentos dos países ligados aos regimes fascistas. A expansão de suas organizações e atividades alarmou o governo brasileiro que passou a controlá-las. Os poloneses também foram incluídos nesse controle, pois possuíam relação com o consulado polonês que investia nas escolas polonesas.

Diante disso e do projeto de nacionalização empreendido pelos republicanos, desde o início do século XX, as escolas étnicas sofreram com as constantes fiscalizações para adaptarem-se às leis de nacionalização. Nesse caso, conforme Kreutz (1997, p. 135), pela questão étnica se percebe o significado e se compreende as relações complexas entre diversas formas de interações humanas. A etnia não é uma categoria pronta e estática, mas dinâmica, possível de transformação. (KREUTZ, 1997, p. 137). A política nacionalista propunha com essas interferências, eliminar o que era étnico e nacionalizar essas escolas comunitárias de imigrantes. Para o Estado não era interessante fechá-las, mas alterar o seu caráter.

As escolas étnicas polonesas mantinham dois currículos: um em português, fiscalizado pela Secretaria da Educação, e um complementar destinado aos filhos de imigrantes e fiscalizado pelo governo polonês. (ESCOLA VICENTINA, 2000). De acordo com Wachowicz (2002, p. 83), o período da manhã era destinado ao programa polonês e o da tarde ao brasileiro. No Paraná, durante a década de 1920, além do Código de Ensino de 1917, outras duas leis controlavam as escolas étnicas: a lei 2005 de 1920 e a lei 2157 de 1922. A primeira estabeleceu que fosse obrigatório o ensino em língua vernáculo, língua portuguesa, história e corografia do Brasil. A segunda, complementava a primeira com uma série de determinações, destacando-se o respeito aos feriados nacionais, o ensino em vernáculo, com exceção das línguas estrangeiras, em pelo menos quatro aulas por semana, sendo três dedicadas à Geografia, Corografia e História do Brasil, por professores reconhecidos. A escola deveria ser submetida sem aviso prévio às autoridades e à inspeção médico-escolar. (WACHOWICZ, 2002, p. 47).

$\mathrm{Na}$ escola das Irmãs da Caridade se oferecia o primário, para meninas e meninos entre 7 e 14 anos, e o jardim-de-infância, para crianças de 4 a 7 anos, conforme estabelecia os artigos 32 e 41 do Código de Ensino de 1917. Segundo Wachowicz (2002, p. 72), os jardins-de-infância eram pré-escolas que utilizavam somente o polonês, o que não era ilegal 
perante as leis paranaenses, pois as crianças não tinham idade suficiente para dominar a língua portuguesa, cujo ensino começava no primário. Panko (1999, p. 18-20) relatou que em casa só se falava em polonês e os pais tinham dificuldade de fazer compras, pois não sabiam falar e não entendiam o português. Percebe-se que é na escola que os filhos dos poloneses aprendiam o português, o que era imposto pelas leis de nacionalização, e para facilitar a aprendizagem era necessário professoras que soubessem os dois idiomas. Por isso, as religiosas faziam exames de língua portuguesa para tornarem-se aptas a abrir escolas e ensinar. Evidencia-se, também, que as crianças polonesas fariam uma extensão do nacionalismo brasileiro em casa ao falarem ou ajudarem os pais com a língua portuguesa. Pela língua, a escola abrasileirava os poloneses.

Nas lembranças de Verônica Sidoski, as aulas eram ministradas em dois períodos. Pela manhã, no idioma português e à tarde (até as duas horas), no idioma polonês. Por isso, a escola possuía o atendimento para alunos externos e semi-internos. Verônica Sidoski relatou que havia muitos alunos na escola, o ensino era pago e para o almoço levavam pão para se alimentar. (FILLOS, 2008, p. 50). No currículo polonês se ensinava a ler e escrever em polonês e a história da Polônia, conforme a lembrança de Verônica Sidoski. Como a escola mantinha esse caráter particular com dois currículos, estudavam os filhos dos poloneses e também os filhos dos brasileiros.

As primeiras irmãs eram de origem polonesa e foram Irmã Helena Olek, supervisora e diretora da escola, lecionou várias matérias de classe; Irmã Gabriela Kulerska, descendente da nobreza da Polônia, dedicou toda a vida ao ensino da música e pintura. Seguiam-se de perto, Irmã Marta Flizikowski e Irmã Zeferina. (ZENI, 1990). Além dessas, foram lembradas as Irmãs Severina Noga, Edwirges Miketa e a Irmã Madalena, que não era polonesa. Segundo Verônica Sidoski, os alunos de $1^{\mathrm{a}}$ e $2^{\mathrm{a}}$ séries estudavam numa sala com a Irmã Miketa e na outra $3^{a}$ e $4^{a}$ séries com a Irmã Severina Noga. (FILLOS, 2008, p. 50). Panko (1999) escreveu que ela e os outros alunos gostavam muito de estudar com a Irmã Zeferina, que veio da Polônia, e as aulas eram somente em polonês. Para Antônio Pavelski Sobrinho, entrevistado pelo autor, as irmãs falavam muito bem o polonês e tinham dificuldade de falar o português. Depois, por já estarem acostumadas, conversavam normalmente, mas com um sotaque polonês. (PAVELSKI, 2001).

Para alfabetizar as crianças em polonês, era utilizada a Cartilha para as crianças polonesas no Brasil - Elementarz dla dzieci polskich w Brazylji desenvolvida por Konstanty Lech, professor graduado na Polônia, sobre a orientação pedagógica das escolas polonesas. (WACHOWICZ, 2002, p. 82). A cartilha seguia o método analítico e o processo de palavração. Cada lição partia de uma palavra básica, a qual era ilustrada por um desenho. As crianças reconheciam as palavras e gravavam sua forma. Depois que estivessem seguras do conhecimento, a palavra era dividida em sons, escrita no quadro e abaixo as letras separadas. Elas liam a letra (som), desenhavam no ar com o dedo, depois nas mesas e por fim nas lousas. Portanto, aprendiam pelos sons. (WACHOWICZ, 2002, p. 88). 


\section{Revista HIIS'TNDIBR On-lime}

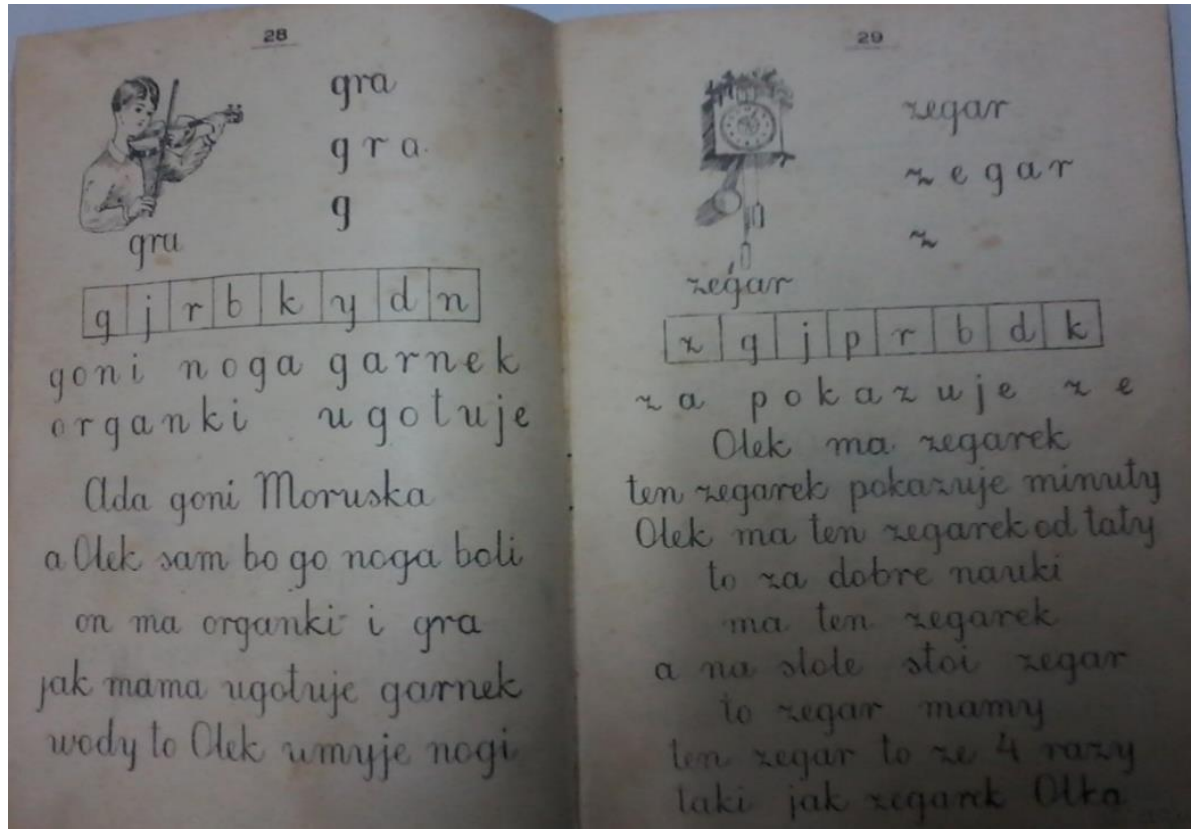

Figura para 05 - Método da Cartilha as crianças polonesas no Brasil. Fonte: CEDOC/I - Centro de Documentação e Memória da Unicentro/Irati.

Verônica Sidoski, ao lembrar das aulas de leitura e escrita em polonês, mencionou o uso desses manuais didáticos. Disse que havia cartilhas e outros livros também, inclusive um em polonês, que não lembrou o nome.

Era também uma cartilha e era bastante difícil a escrita e a pronúncia de algumas palavras. Relógio, por exemplo, eu não conseguia pronunciar. Em polonês é zegarek. Na cartilha tinha a figura de uma lombriga, cuja pronúncia é dzdzownica. São pequenas coisas que marcam a gente!(FILLOS, 2008, p. 51).

A descrição refere-se à cartilha para as crianças polonesas no Brasil-Elementarz dla dzieci polskich w Brazylji. Entre os livros mencionados por ela, estão os livros de leitura com textos específicos para cada classe.

As práticas religiosas católicas continuavam sendo realizadas na escola das Irmãs da Caridade e faziam parte do cotidiano dos alunos. Zeni (2001) relatou que antes das aulas, assistir à missa era um dever e um prazer, uma grande novidade para as crianças. Na escola havia o internato para atender aos filhos dos colonos poloneses que moravam em lugares longínquos e principalmente para a preparação religiosa, como a Primeira Comunhão. (FERREIRA, 1974, p. 20). O bispo de Ponta Grossa, D. Antônio Mazzarotto sempre vinha à Irati e realizava celebrações religiosas na escola das Irmãs da Caridade. Era uma oportunidade para espalhar os ideais da Igreja e manter a catolicidade da comunidade polonesa conforme os princípios romanizantes. A Igreja Católica tinha a educação como estratégia e nas escolas se incutia hábitos e valores conforme esses princípios. 


\section{Revista HIIST'NADBR On-lime}

\begin{tabular}{ll}
\hline Artigo & doi: $10.20396 /$ rho.v17i2.8645437 \\
\hline
\end{tabular}

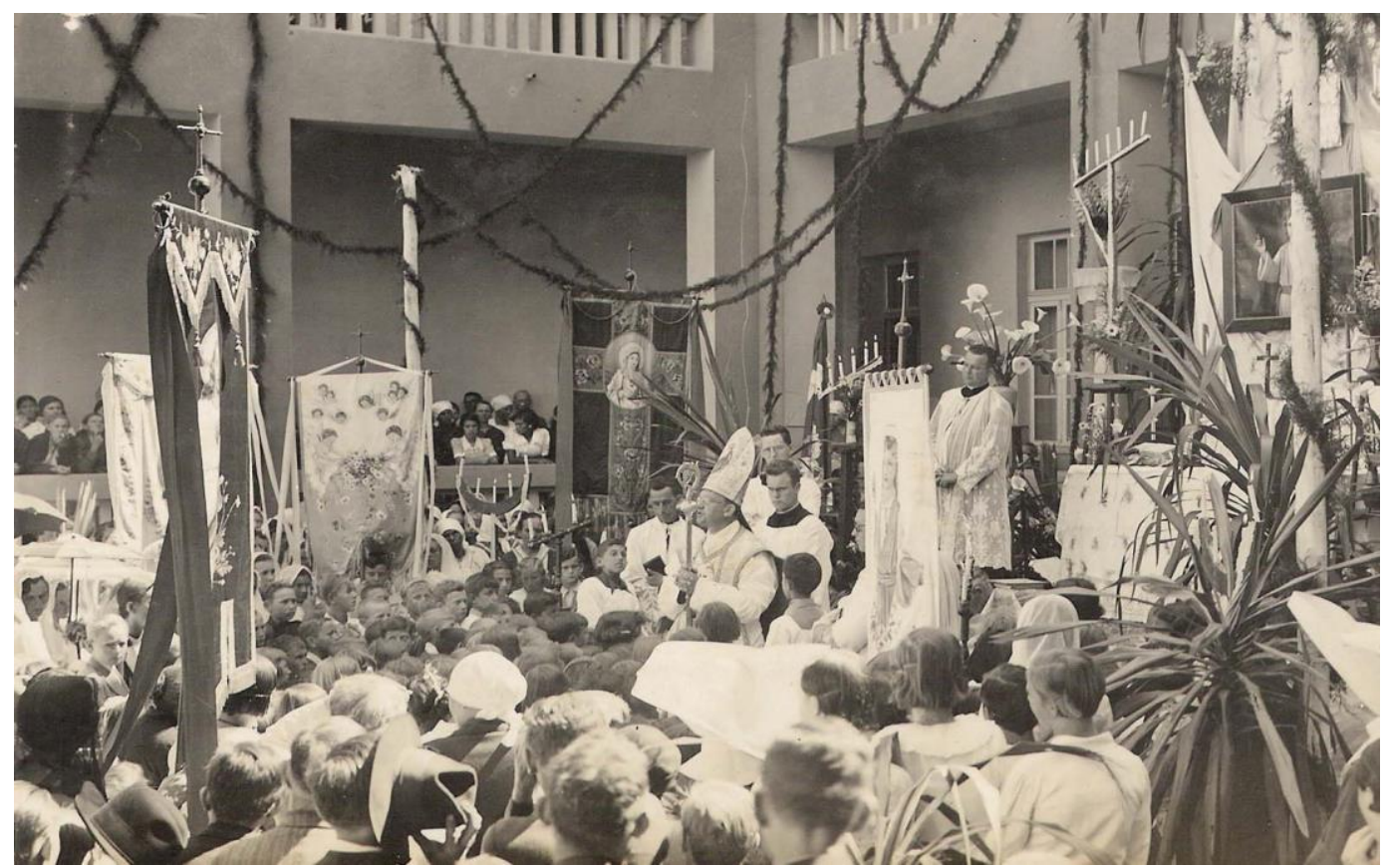

Figura 06 - Celebração religiosa na Escola Nossa Senhora das Graças, com o bispo D.

Antônio Mazzarotto.

Fonte: Casa da Cultura/Museu Municipal de Irati e CEDOC/I.

Percebe-se o quanto a língua e a religião eram essenciais para a preservação da identidade étnica dos poloneses. A ligação que os poloneses tinham com o sentimento pátrio do país de origem de seus antepassados misturava-se com a fé. Por isso, esses elementos simbólicos são característicos da etnia polonesa e expressam a realidade tensa e contraditória vivida por eles nas práticas sócio-culturais.

Em 1937, as escolas étnicas foram fechadas. O governo temeu que nas comunidades de estrangeiros se formassem núcleos particulares, desligados da política nacionalista. Nessa época, o governo do Paraná havia estabelecido o Código de Ensino de 1937 para organizar a educação estadual e no qual se baseou o decreto $n^{\circ} 6149$ de 10 de janeiro de 1938 instituído pelo interventor Manoel Ribas para regulamentar o ensino paranaense em bases nacionalistas. (RENK, 2009, p. 173). O decreto assegurava o funcionamento dos estabelecimentos particulares desde que obedecessem à várias disposições, as quais afetavam diretamente os professores e diretores estrangeiros. Os professores de língua portuguesa, história e geografia deveriam ser brasileiros natos e os diretores, brasileiros ou naturalizados. O ensino primário e o jardim-de-infância deveriam ensinar no vernáculo. Essas medidas objetivavam a nacionalização das escolas e o fim da subvenção estrangeira das escolas particulares. Para tanto, o governo de Manoel Ribas deu continuidade à política de fiscalização e inspeção das escolas para verificar se todas estavam ensinando a língua nacional e seguindo o programa oficial. (RENK, 2009, p. 167-169). Nas escolas étnicas polonesas, o ensino em língua polonesa foi proibido.

Junto desse projeto nacionalista, estava em jogo o interesse da Igreja Católica. Diante de uma população amplamente religiosa, a política nacionalista poderia sofrer críticas e reações e o governo não poderia estar contrário à Igreja. Ao incluí-la no seu projeto de 
nacionalização, algumas escolas existentes nesses núcleos mantiveram-se abertas e oficialmente reconhecidas pelo governo. (BOMENY, 1999, p. 142). Com relação às escolas mantidas por congregações religiosas, o artigo 11 do decreto-lei ${ }^{\circ} 1545$ de 1939 permitia que as congregações religiosas especializadas que mantinham institutos em todos os países, sem relação alguma com qualquer nacionalidade, tivessem diretores estrangeiros. (BRASIL, 1939). No caso da escola das Irmãs da Caridade, em Irati, a Irmã Helena Olek manteve-se na direção até 1946, mesmo sendo polonesa. Contudo, a escola deixava de ser vinculada à comunidade polonesa, pois, com os decretos-leis de nacionalização, a escola das Irmãs da Caridade foi autorizada a funcionar oficialmente com o nome de Colégio Nossa Senhora das Graças pelo decreto estadual $\mathrm{n}^{\circ} 6149$ de 10 de janeiro de 1938, enquadrando-se às escolas oficiais do Paraná e deixando de ensinar em língua polonesa.

O Estado não foi contrário às escolas religiosas. Elas faziam parte da ampliação da influência e da área de domínio da Igreja Católica, que buscava inserir na sociedade os princípios romanizantes. A Igreja estava próxima dos imigrantes poloneses, uma agressão a ela poderia gerar revolta por parte dessa população e os conflitos não faziam parte da política nacionalista. Por isso, preservava-se o projeto de nação sem interferir no projeto romanizante. O Estado percebeu que não teria sucesso sem a parceria da Igreja Católica e, numa negociação em benefício de ambos, manteve as escolas católicas, mas nacionalizadas. A Igreja seria então responsável pela criação da identidade nacional, na qual estavam inseridos os valores cristãos.

A atuação das Irmãs da Caridade em Irati-Paraná continuou nas décadas seguintes com primário, ginásio e escola normal. Desde 1996, a Escola Municipal Irmã Helena Olek oferece os anos iniciais e a Escola Estadual Nossa Senhora das Graças os anos finais do ensino fundamental.

\section{ALGUMAS CONSIDERAÇÕES}

As Irmãs da Caridade polonesas garantiram a transmissão dos valores religiosos e étnico-culturais aos filhos dos imigrantes, mas carregavam junto com a questão étnica os interesses expansionistas da Igreja Católica. A política de nacionalização impediu a continuidade das escolas étnicas e as exigências oficiais as destituíram. Algumas escolas religiosas continuaram abertas, desde que nacionalizadas, mas garantindo o objetivo da Igreja. A língua polonesa e a religiosidade ficaram registradas na memória dos ex-alunos e nas fotografias da Escola Nossa Senhora das Graças como pistas que possibilitaram essa análise da história da educação sob uma perspectiva étnica. $\mathrm{O}$ acordo estabelecido entre Estado e Igreja manteve os seus interesses de formar cidadãos brasileiros e católicos. Contudo, o que era étnico ficou excluído do processo. Os filhos dos imigrantes continuavam católicos, mas brasileiros.

Mesmo que as lembranças não transmitam uma verdade absoluta, devido à memória ser variável e sofrer esquecimentos, as pistas mostram a preocupação dos imigrantes com a educação e o significado que a escola possuía nas relações sociais e culturais. Contudo, não se considera essas lembranças como uma noção de verdade absoluta e objetiva, mas não deve desconsiderar a contribuição para a análise da história. Essa narrativa demonstra a possibilidade de reunir pequenos indícios para entender uma realidade mais complexa. Para 
tanto, precisou-se entrelaçar as lembranças existentes nos lugares de memória, fragmentos que permitiram produzir um "saber venatório".

$\mathrm{O}$ artigo torna-se uma colaboração para fornecer dados e motivar pesquisas que envolvam a etnia polonesa, suas práticas e representações. A falta de fontes devido aos silêncios desse processo histórico escolar que envolveu uma gama de relações tensas e conflituosas, ao extravio motivado pela repressão nacionalista ou ao não conhecimento de seus lugares torna-se um problema a ser considerado, mesmo com a existência de algumas iniciativas familiares e institucionais. Irati foi uma importante colônia de imigrantes poloneses no Estado do Paraná. As representações dessa cultura se encontram visíveis na área urbana e rural, mas a história é desconhecida. Um exemplo é a Escola Nossa Senhora das Graças. Poucos sabem de sua origem étnica. A análise indiciária iniciada por essa premissa pode alargar o envolvimento dos iratienses em questões que expliquem o silêncio dos descendentes de poloneses no tocante às práticas e à identidade cultural. E isso merece um estudo mais aprofundado.

\section{REFERÊNCIAS}

I LIVRO TOMBO DE IRATY (1920-1966). Acervo da Paróquia Nossa Senhora da Luz.

\section{BAlHANA, A. P. Política imigratória do Paraná. Revista Paranaense de}

Desenvolvimento, Curitiba, n. 87 p. 39-50, jan./abr. 1996.

BITTENCOURT, C. M. F. Pátria, civilização e trabalho: o ensino de história nas escolas paulistas (1917-1939). São Paulo: Loyola, 1990.

BOMENY, H. M.B. Três decretos e um ministério: a propósito da educação no estado novo. In: PANDOLFI, D. C. (Org.). Repensando o Estado Novo. Rio de Janeiro: FGV, 1999. p. 137-166.

BRASIL. Decreto-lei no 1545 de 25 de agosto de 1939. Dispõe sobre a adaptação ao meio nacional dos brasileiros descendentes de estrangeiros. Disponível em: $<$ http://www2. camara.leg.br/legin/fed/declei/1930-1939/decreto-lei-1545-25-agosto-1939-411654publicacaooriginal-1-pe.html>. Acesso em: 15 jul. 2016.

CAPRI, E. J. De católicos poloneses a ponta-grossenses católicos: a escola sagrada família: 1933-1945.2003. 219 f. Dissertação (Mestre em História) - Universidade Federal do Paraná Setor de Ciências Humanas, Letras e Artes, Curitiba, 2003.

CELEBRAÇÃO RELIGIOSA na Escola Nossa Senhora das Graças, com o bispo D. Antônio Mazzarotto. 1 fotografia, P\&B. Casa da Cultura/Museu Municipal de Irati e CEDOC/I.

CHAIBE, V. "Nos olhos nostalgia... nos lábios sempre uma história". Jornal Hoje Centro Sul. Irati, p. 10, 10 a 16 de jul. 2002. n. 120. Acervo do autor. 
CONSTRUÇÃO DA Escola Nossa Senhora das Graças. Ao fundo, Igreja São Miguel. 1 fotografia P\&B. CEDOC/I - Centro de Documentação e Memória da Unicentro/Irati.

CRISSI, R. Entrevista. Irati, 3 jan. 2002. Concedeu entrevista a Fábio Kruk em sua residência, à Rua Cel. Emílio Gomes. Faleceu em 2007.

ESCOLA NOSSA Senhora das Graças. 1938. [193?]. 1 fotografia, P\&B. Casa da Cultura/Museu Municipal de Irati.

ESCOLA VICENTINA. Plano da comissão especializada de educação das instituições educacionais Vicentinas. Curitiba, 2000.

FARAH, A. L. S.; GUIL, C.; PHILLIPI, S. J. Irati 100 anos. Curitiba: Arte, 2008.

FERREIRA, A. Província de Curitiba 1904-1974. Curitiba: Vicentina, 1974.

FILLOS, L. M. A educação matemática em Irati (PR): memórias e história. 2008. 228 f. Dissertação (Mestrado em Educação) - Universidade Federal do Paraná, Curitiba, 2008.

GINZBURG, C. Sinais: raízes de um paradigma indiciário. In: GINZBURG, C. (Org.). Mitos, emblemas, sinais: morfologia e história. São Paulo: Companhia das Letras, 1989.

GLUCHOWSKI, K. Os poloneses no Brasil: subsídios para o problema da colonização polonesa no Brasil. Tradução: Mariano Kawka. Porto Alegre: Rodycz \& Ordakowski, 2005 .

GÓRAL, J.Srebrny Jubileusz Polskich Sióstr Milosierdzi w Poludniowej Braylji. Curitiba: Lud, 1929. p. 76. Acervo do CEDOC/I - Centro de Documentação e Memória da Unicentro/Campus de Irati.

INSTALAÇÕES PROVISÓRIAS da escola das Irmãs da Caridade, 1930. [1930?]. 1 fotografia. Casa da Cultura/Museu Municipal de Irati.

KREUTZ, L. Escolas étnicas no Brasil e a formação do Estado Nacional: a nacionalização compulsória das escolas de imigrantes (1937-1945). Poiésis, v. 3, n. 5, p. 71-84, jan./jun. 2010 .

KREUTZ, L. História da educação a partir da perspectiva de etnia: reflexões introdutórias. História da Educação, Pelotas, v. 1, n. 2, p. 127-143, set. 1997.

KRUK, F. Resolver os conflitos para instituir a paróquia: Capela Nossa Senhora da Luz (1900-1920). In: SEMANA DE HISTÓRIA EM IRATI E SÉMINARIOS DE ESTUDOS ÉTNICO-RACIAIS, 9., 2014, Irati, PR. Anais eletrônico... Irati, PR: Ensino de história debates contemporâneos, 2014. Disponível em: <http://anais.unicentro.br/semanadehistoria /pdf/ixv1n1/60.pdf>. Acesso em: 27 jun. 2017. 
KRUTZ, L. A educação de imigrantes no Brasil. In: LOPES, E. M.; FARIA FILHO, L.M.; VEIGA, C. G. 500 anos de educação no Brasil. 3. ed. Belo Horizonte: Autentica, 2003. p. 347-370.

KUBASKI, L. Imigração e educação dos poloneses em Ponta Grossa, Paraná. 2015. 115 f. Dissertação (Mestrado em Educação) - Universidade Estadual de Ponta Grossa, Ponta Grossa, 2015.

MEIHY, C. S. B. Manual de história oral. São Paulo: Loyola, 1996.

MÉTODO DA Cartilha para as crianças polonesas no Brasil. 1 imagem. CEDOC/I Centro de Documentação e Memória da Unicentro/Irati.

NORA, P. Entre memória e história: a problemática dos lugares. Projeto História, v. 10, p. 7-28, dez. 1993.

ORREDA, J. M. Colégio N.S. das Graças comemora cinqüentenário. Jornal O Debate. Irati, 20 set. 1980, n. 327. Acervo da Casa da Cultura/Museu Municipal de Irati.

PANKA, A. F. Bondade, carinho, simplicidade. D. Antonia nos conta.Depoimento escutado em sua residência e escrito pelos alunos. Histórico e biografias de alunos que estudaram na escola. Datilografado, 1985. Cópia do acervo da Escola Nossa Senhora das Graças.

PANKO, P. S. História da minha vida. In: ORREDA, J. M. (Org.). História de vida e sonhos. UATI, out. 1999. p. 18-20. Acervo da Biblioteca Pública Municipal de Irati.

PARANÁ (Estado). Relatório do secretário de Estado de Negócios de Obras Públicas e Urbanização. Engenheiro Francisco Gutierrez Beltrão, em 14 jan. 1908. Curitiba, Oficina de Artes Gráfica, 1908.

PAVELSKI, S. A. Entrevista. Irati, ago. 2001.Concedeu entrevista a Fábio Kruk, em sua residência, juntamente com sua irmã Therezinha Hessel. Faleceu em 22 de março de 2013.

PEREIRA, E. Entrevista. Irati, fev. 2002. Concedeu entrevista a Fábio Kruk em sua residência. Faleceu em 2006.

PESAVENTO, S. J. História e história cultural. Belo Horizonte: Autêntica, 2003.

PROCISSÃO RELIGIOSA. No canto superior direito, Igreja Nacional Polonesa. 1 fotografia, P\&B. Casa da Cultura/Museu Municipal de Irati e CEDOC/Unicentro.

RENK, V. E. Aprendi a falar português na escola! O processo de nacionalização das escolas étnicas polonesas e ucranianas no Paraná. 2009. 241 f. Tese (Doutorado em Educação) - Universidade Federal do Paraná, Curitiba, 2009.

SILVA, V. L. G. da. Vitrines da República: os grupos escolares em Santa Catarina (18891930). In: VIDAL, D. G. (Org.). Grupos Escolares: cultura escolar primária e 
escolarização da infância no Brasil (1893-1971). Campinas: Mercado de Letras, 2006. p. 341-376.

SOCIEDADE BENEFICENTE CULTURAL IRATIENSE: LXXV ANIVERSÁRIO. Histórico integrante dos preparativos para a celebração do LXXV aniversário do Clube Polonês. Artes gráficas, Castro Kugler, 1996.

THOMPSON, P. A voz do passado: história oral. Tradução de Lólio Lourenço de Oliveira. Rio de Janeiro: Paz e Terra, 1992.

VALENGA, G. Irati: minha vida, nossa história. Guarapuava: Ed. da UNICENTRO, 2002.

WACHOWICZ, R. C. As escolas da colonização polonesa no Brasil. Curitiba: Champagnat, 2002.

WACHOWICZ, R. C. História do Paraná. Curitiba: Vicentina, 1997.

WACHOWICZ, R. C. O camponês polonês no Brasil. Curitiba: Casa Romário Martins, 1981. p. 93-113.

ZANLORENZI, C. M. P. Reconstrução histórica do primeiro grupo escolar de Irati-Paraná. Revista HISTEDBR On-line, Campinas, v. 12, n. 45, p. 49-63, ago. 2012. Disponível em: <https://periodicos.sbu.unicamp.br/ojs/index.php/histedbr/article/view/8640107>. Acesso em: 16 jun. 2017.

ZENI, G. B. Colégio Nossa Senhora das Graças. Texto elaborado para a obra Educação em Irati, 2001. Cópia do acervo de José Maria Orreda.

ZENI, O. G. Discurso. Discurso elaborado para as festividades alusivas aos 60 anos do Colégio Nossa Senhora das Graças. Datilografado, 18 mar. 1990. Cópia do acervo de Olga Grechinski Zeni.

Notas

${ }^{1}$ Discente do Programa de Pós-graduação stricto sensu em Educação da Unicentro - Universidade Estadual
do Centro-Oeste. Linha de pesquisa: Políticas Educacionais, História e Organização da Educação. Orientadora:
${\text { Profa }{ }^{a} \text { Dra }^{a} \text { Luciane Neuvald. E-mail: fabiokruk @ yahoo.com.br }}^{2}$ Natural de Irati-Paraná, Antonio Pavelski Sobrinho nasceu em 1939. Formou-se em Ciências, Pedagogia,
Técnicas Industriais e Técnicas Comerciais, lecionou durante 30 anos em Irati. Foi Secretário Municipal de
Educação de Irati. Aposentou-se em 1995. Estudou o primário na Escola Nossa Senhora das Graças, tendo
completado seus estudos no Colégio São Vicente de Paulo e curso superior em Curitiba. Descendente de
poloneses, seus avós eram naturais da Polônia. Seu pai, Alexandre Pavelski, foi o primeiro a receber as Irmãs
da Caridade na estação ferroviária.
${ }^{3}$ Edvirges Pereira, popularmente conhecida por Dona Vica, natural de Irati, sempre residiu à Rua Cel. Grácia,
a poucos metros do Clube Polonês (Sociedade Liberdade) onde estudou suas primeiras séries e aprendeu a 
língua de seus descendentes. Dona Vica concluiu o primário na Escola Nossa Senhora das Graças, quando ainda funcionava em instalações provisórias.

${ }^{4}$ Romeu Crissi nasceu em Guarapuava em 1910, onde estudou até o segundo ano do ginásio. Chegou a Irati em dezembro de 1930. Seu primeiro emprego foi no escritório de representação dos bancos, mantido por Antônio Xavier da Silveira. Atuou como juiz de paz por mais de 40 anos.

Submetido em: 29/04/2016

Aprovado em: 06/07/2017 